\title{
SYNTHESIS, CHARACTERISATION AND ANTIMICROBIAL ACTIVITY OF NEW NICOTINAMIDE-THIAZOLE DERIVATIVES
}

\author{
H. Venkatasubramanian ${ }^{1,3}$, Sarojkumar Sha ${ }^{2}$, S. Hemalatha ${ }^{2}$ \\ and D. Easwaramoorthy ${ }^{1, *}$ \\ ${ }^{1}$ Department of Chemistry, B.S.Abdur Rahman Crescent Institute of Science and Technology, \\ Vandalur, Chennai-600 048, Tamilnadu, India. \\ ${ }^{2}$ School of Life Science, B.S.Abdur Rahman Crescent Institute of Science and Technology, \\ Vandalur, Chennai-600048, India. \\ ${ }^{3}$ Department of Chemistry, Madras Institute of Technology Campus, Anna University, \\ Chennai-600044, Tamilnadu, India. \\ *E-mail: easwar@crescent.education
}

\begin{abstract}
In this era, the identification or synthesis of a new antibiotic is important research due to the pollution and harmful bacterial pathogens. Hence this work selected the already known mild active molecules such as Nicotinamide and Thiazole to enhance the activity against the disease-causing pathogens. Using peptide coupling reagent EDCI, nine compounds were prepared and characterized by ${ }^{1} \mathrm{H}$ NMR, Mass spectroscopy. The characterized compounds were evaluated In vitro antibacterial and antifungal activity against Staphylococcus aureus, Staphylococcus epidermidis, Escherichia coli, Klebsiella pneumonia, Candida albicans by broth dilution method and zone of inhibition measured in millimeter. All the derivatives showed good to moderate activity. Out of nine compounds N-(4-(thiomorpholine4-carbonyl) thiazol-2-yl) nicotinamide showed better zone of inhibition between $27 \mathrm{~mm}$ and $34 \mathrm{~mm}$. the outcomes of the result revealed that the diamide bond acts as an important pharmacophore and exposed the good inhibition behavior.
\end{abstract}

Keywords: Nicotinamide, Thiazole, Antimicrobial Activity, Amide Bond

CRASĀYAN. All rights reserved

\section{INTRODUCTION}

Different infectious microbes have increased and are causing harmful diseases to human beings and are also causing death across the world. ${ }^{1}$ So, enhanced new antibiotic research received more attention between the researchers to involve in design and synthesis of the new active molecules. Based on the society based theme, this work investigated the already reported mild active molecules such as Nicotinamide and thiazole for this research. Nicotinamide is a pyridine ring containing vitamin $\mathrm{B}_{3}$ and prevents deficiency syndrome pellagra. ${ }^{2,3}$ Similarly, Thiazole ring also the active moiety and present in many bio-natural products like thiamine (vitamin B1). 5 Thiazole derivatives are exhibited the therapeutic activities such as antimicrobial, antitumor, anti-HIV, analgesic and anti-inflammatory. ${ }^{6-12}$ After the selection of the reactant molecules, this work identified the easily absorbing functional group amide from the reported researches. ${ }^{13-15}$ Using the reported researches, this research derived the new series of compounds and was characterized by ${ }^{1} \mathrm{H}-\mathrm{NMR}$, Mass spectral techniques. The characterized compounds inhibiting ability were measured by broth dilution method against Staphylococcus aureus, Staphylococcus epidermidis, Escherichia coli, Klebsiella pneumonia, Candida albicans and the outcomes were measured in zone of inhibition with the unit of millimeter.

\section{EXPERIMENTAL}

The solvents and reagents were purchased from Sigma-Aldrich (India), Biocorporals, Chennai. Solvents were dried over Type 3A molecular sieve for 72 hours, followed by distillation under reduced pressure.

Rasayan J. Chem., 12(4), 2005-2010(2019)

http://dx.doi.org/10.31788/RJC.2019.1245321

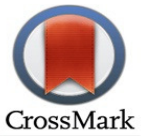




\title{
RASĀYAN J. Chem.
}

Vol. 12 | No. 4 |2005 - 2010| October - December | 2019

${ }^{1} \mathrm{H}-\mathrm{NMR}$ spectra were recorded on a BRUCKER $400 \mathrm{MHZ}$ Instrument (DMSO- $\mathrm{d}_{6}$ used as solvent) and TMS used as an internal standard. Using Jeol-JMS D-300 spectrometer, mass spectra of the derivatives were recorded. Anti-bacterial strains of American Type Culture Collection (ATCC), Rockville, USA such as Staphylococcus aureus (ATCC 6538), Staphylococcus epidermidis (ATCC 14990), Escherichia coli (ATCC 25922), Klebsiella pneumonia (ATCC 13883), and Candida albicans (ATCC 10231) were purchased from the Department of Microbiology, Ceeal Analytical Lab, Chennai, TamilNadu.. All reactions are monitored by 60:40 ethyl acetate, hexane mixture. Nutrients agar medium and dextrose agar medium (Hi-Media Laboratories, Mumbai, India) were the media used for the study of anti-bacterial and anti-fungal respectively.

\section{General Procedure}

Synthesis of Ethyl 2-(Nicotinamido)Thiazole-4-Carboxylate (3)

$5 \mathrm{~g}$ ( $0.0406 \mathrm{~mol})$ of Nicotinic acid (1) was treated with $50 \mathrm{~mL}$ dried DMF and $15.5 \mathrm{~g}$ of 1-Ethyl-3-(3'Dimethylamino) Carbodiimide hydrochloride salt (EDCI, $0.0812 \mathrm{~mol}$ ) then $5.48 \mathrm{~g}$ of Hydroxy Benzotriazole (HOBt, $0.0406 \mathrm{~mol}$ ) were added and stirred under nitrogen atmosphere at $0^{\circ} \mathrm{C}$ for 30 minutes. After $15 \mathrm{~min} 9 \mathrm{~g}$ of ethyl-2-aminothiazole-4-carboxylate (2) $(0.0487 \mathrm{~mol})$ and $20 \mathrm{~mL}$ of N, N-Diisopropylethylamine (DIPEA $0.122 \mathrm{~mol}$ ) were added slowly over the period of $10 \mathrm{~min}$. The reaction mixture was stirred for 4 hours at room temperature and the reaction was monitored by TLC using $60 \%$ ethyl acetate with Hexane. After the reaction completion, reaction mass poured into ice water. The brown solid was filtered and dried under vacuum at $50^{\circ} \mathrm{C}$. The yield obtained was $85 \%$.

\section{Synthesis of 2-(Nicotinamido) Thiazole-4-Carboxylic Acid (4)}

The dried and characterized product was carried for the conversion of carboxylic acid. $10 \mathrm{~g}(0.034 \mathrm{~mol})$ of compound 3 was added in $100 \mathrm{~mL}$ of THF with $2.72 \mathrm{~g}$ of sodium hydroxide in $25 \mathrm{ml}$ of water at $10^{\circ} \mathrm{C}$. After the addition, the reaction mixture was stirred for 2 hours at room temperature. THF solvent was evaporated under high vacuum after the completion of the reaction. The reaction mass was cooled below $10^{\circ} \mathrm{C}$ and neutralized using $10 \% \mathrm{HCl}$. The white precipitate formed was filtered and dried. Finally, the $78 \%$ of $(7 \mathrm{gm})$ compound $\mathbf{4}$ was obtained and carried for the next stage.

\section{Preparation of N-Substituted-2-(Nicotinamido) Thiazole-4-Carboxamide (5a-i)}

As discussed in compound $\mathbf{3}$ preparation, the reaction carried for the preparation of $5 \mathrm{a}$ to 5 i derivatives. 1: 1.2 equivalents of the compound $\mathbf{4}$ and substituted amines were used for the synthesis. The reaction mass poured into ice water and the brown color solid was filtered and dried under vacuum at $60^{\circ} \mathrm{C}$ for $3 \mathrm{hrs}$.

\author{
${ }^{1}$ H- NMR Characterization of Compounds \\ Ethyl 2-(nicotinamido) thiazole-4-carboxylate (3) \\ ${ }^{1} \mathrm{H}-\mathrm{NMR}\left(400 \mathrm{MHz}, \mathrm{CDCl}_{3}\right) \delta(\mathrm{ppm}) 12.3(\mathrm{~b}, 1 \mathrm{H}), 9.15(\mathrm{~s}, 1 \mathrm{H}), 8.75(\mathrm{~d}, 1 \mathrm{H}), 8.30(\mathrm{~d}, 1 \mathrm{H}), 8.10(\mathrm{~s}, 1 \mathrm{H})$, \\ $7.50(\mathrm{t}, 1 \mathrm{H}), 4.4(\mathrm{q}, 2 \mathrm{H}), 1.30(\mathrm{t}, 3 \mathrm{H}) ; \mathrm{m} / \mathrm{z}: 278(\mathrm{M}+1)$.
}

2-(nicotinamido) thiazole-4-carboxylic acid (4)

${ }^{1} \mathrm{H}-\mathrm{NMR}\left(400 \mathrm{MHz}\right.$, DMSO-d $\left.\mathrm{d}_{6}\right) \delta(\mathrm{ppm}) 12.5$ (b, 1H), 11.1 (s, 1H), 9.15 (s, 1H), $8.75(\mathrm{~d}, 1 \mathrm{H}), 8.30$ (d, $1 \mathrm{H}), 8.20(\mathrm{~s}, 1 \mathrm{H}), 7.50(\mathrm{t}, 1 \mathrm{H}) ; \mathrm{m} / \mathrm{z}: 248(\mathrm{M}-1)$

\section{2-(nicotinamido)-N-phenylthiazole-4-carboxamide (5a)}

${ }^{1} \mathrm{H}-\mathrm{NMR}\left(400 \mathrm{MHz}\right.$, DMSO-d $\left.\mathrm{d}_{6}\right) \delta(\mathrm{ppm}) 12.3(\mathrm{~b}, 1 \mathrm{H}), 9.1(\mathrm{~s}, 1 \mathrm{H}), 8.74(\mathrm{t}, 2 \mathrm{H}), 8.30(\mathrm{~d}, 1 \mathrm{H}), 8.10(\mathrm{~s}, 1 \mathrm{H})$, $7.7(\mathrm{~d}, 2 \mathrm{H}), 7.5(\mathrm{t}, 1 \mathrm{H}), 7.30(\mathrm{t}, 2 \mathrm{H}), 7.05(\mathrm{t}, 1 \mathrm{H}) ; \mathrm{m} / \mathrm{z}: 325(\mathrm{M}+1)$

N-cyclopropyl-2-(nicotinamido) thiazole-4-carboxamide (5b)

${ }^{1} \mathrm{H}-\mathrm{NMR}\left(400 \mathrm{MHz}\right.$, DMSO-d $\left.{ }_{6}\right) \delta(\mathrm{ppm}) 12.3(\mathrm{~b}, 1 \mathrm{H}), 9.1(\mathrm{~s}, 1 \mathrm{H}), 8.75(\mathrm{~d}, 1 \mathrm{H}), 8.30(\mathrm{~d}, 1 \mathrm{H}), 8.0(\mathrm{~s}, 1 \mathrm{H})$, $7.55(\mathrm{~d}, 1 \mathrm{H}), 7.5(\mathrm{t}, 1 \mathrm{H}), 3.0(\mathrm{~m}, 1 \mathrm{H}), 0.8(\mathrm{~m}, 2 \mathrm{H}), 0.5(\mathrm{~h}, 2 \mathrm{H}) ; \mathrm{m} / \mathrm{z}: 289(\mathrm{M}+1)$

N-cyclobutyl-2-(nicotinamido) thiazole-4-carboxamide (5c)

${ }^{1} \mathrm{H}-\mathrm{NMR}(400 \mathrm{MHz}$, DMSO-d 6 ) $\delta(\mathrm{ppm}) 12.3(\mathrm{~b}, 1 \mathrm{H}), 9.1(\mathrm{~s}, 1 \mathrm{H}), 8.75(\mathrm{~d}, 1 \mathrm{H}), 8.30(\mathrm{~d}, 1 \mathrm{H}), 8.0(\mathrm{~s}, 1 \mathrm{H}), 7.5$ $(\mathrm{t}, 1 \mathrm{H}), 6.8(\mathrm{~d}, 1 \mathrm{H}), 4.2(\mathrm{~m}, 1 \mathrm{H}), 2.0(\mathrm{~m}, 2 \mathrm{H}), 1.7(\mathrm{~m}, 2 \mathrm{H}), 1.5(\mathrm{~m}, 2 \mathrm{H}) ; \mathrm{m} / \mathrm{z}: 303(\mathrm{M}+1)$ 


\section{RASĀYAN J. Chem.}

Vol. 12 | No. 4 |2005 - 2010| October - December | 2019

N-cyclopentyl-2-(nicotinamido) thiazole-4-carboxamide (5d)

${ }^{1} \mathrm{H}-\mathrm{NMR}\left(400 \mathrm{MHz}\right.$, DMSO-d $\left.{ }_{6}\right) \delta(\mathrm{ppm}) 12.3(\mathrm{~s}, 1 \mathrm{H}), 9.1(\mathrm{~s}, 1 \mathrm{H}), 8.7(\mathrm{~d}, 1 \mathrm{H}), 8.05(\mathrm{~s}, 1 \mathrm{H}), 7.5(\mathrm{t}, 1 \mathrm{H}), 7.15$ $(\mathrm{d}, 1 \mathrm{H}), 4.15(\mathrm{~m}, 1 \mathrm{H}), 1.8(\mathrm{~m}, 4 \mathrm{H}), 1.68(\mathrm{~d}, 1 \mathrm{H}), 1.65(\mathrm{~m}, 2 \mathrm{H}), 1.62(\mathrm{q}, 2 \mathrm{H}) ; \mathrm{m} / \mathrm{z}: 317(\mathrm{M}+1)$

N-cyclohexyl-2-(nicotinamido) thiazole-4-carboxamide (5e)

${ }^{1} \mathrm{H}-\mathrm{NMR}(400 \mathrm{MHz}$, DMSO-d 6 ) $\delta(\mathrm{ppm}) 12.3(\mathrm{~s}, 1 \mathrm{H}), 9.1(\mathrm{~s}, 1 \mathrm{H}), 8.75(\mathrm{~d}, 1 \mathrm{H}), 8.30(\mathrm{~d}, 1 \mathrm{H}), 8.0(\mathrm{~s}, 1 \mathrm{H}), 7.5$ $(\mathrm{t}, 1 \mathrm{H}), 6.5(\mathrm{~d}, 1 \mathrm{H}), 3.5(\mathrm{~d}, 1 \mathrm{H}), 1.6(\mathrm{~m}, 2 \mathrm{H}), 1.4(\mathrm{~m}, 9 \mathrm{H}) ; \mathrm{m} / \mathrm{z}: 331(\mathrm{M}+1)$

$\mathrm{N}-((1 \mathbf{r}, 3 \mathbf{r}, \mathbf{5 r}, 7 \mathrm{r})$-adamantan-2-yl)-2-(nicotinamido) thiazole-4-carboxamide (5f)

${ }^{1} \mathrm{H}-\mathrm{NMR}\left(400 \mathrm{MHz}\right.$, DMSO-d $\left.{ }_{6}\right) \delta(\mathrm{ppm}) 12.3(\mathrm{~s}, 1 \mathrm{H}), 9.1(\mathrm{~s}, 1 \mathrm{H}), 8.75(\mathrm{~d}, 1 \mathrm{H}), 8.30(\mathrm{~d}, 1 \mathrm{H}), 8.05(\mathrm{~s}, 1 \mathrm{H})$, $7.5(\mathrm{t}, 1 \mathrm{H}), 4.05(\mathrm{q}, 1 \mathrm{H}), 2.1(\mathrm{~m}, 2 \mathrm{H}), 1.8(\mathrm{~m}, 13 \mathrm{H}), 0.5(\mathrm{~h}, 2 \mathrm{H}) ; \mathrm{m} / \mathrm{z}: 383(\mathrm{M}+1)$

N-(4-(4-methylpiperazine-1-carbonyl) thiazol-2-yl) nicotinamide (5g)

${ }^{1} \mathrm{H}-\mathrm{NMR}\left(400 \mathrm{MHz}\right.$, DMSO-d $\left.\mathrm{d}_{6}\right) \delta(\mathrm{ppm}) 12.2(\mathrm{~s}, 1 \mathrm{H}), 9.1(\mathrm{~s}, 1 \mathrm{H}), 8.75(\mathrm{~d}, 1 \mathrm{H}), 8.28(\mathrm{~d}, 1 \mathrm{H}), 8.0(\mathrm{~s}, 1 \mathrm{H}), 7.5$ (t,1H), $3.7(\mathrm{~m}, 2 \mathrm{H}), 3.2(\mathrm{~m}, 4 \mathrm{H}), 2.7(\mathrm{dd}, 2 \mathrm{H}), 2.2(\mathrm{~s}, 3 \mathrm{H}) ; \mathrm{m} / \mathrm{z}: 332(\mathrm{M}+1)$

N-(4-(morpholine-4-carbonyl) thiazol-2-yl ) nicotinamide (5h)

${ }^{1} \mathrm{H}-\mathrm{NMR}\left(400 \mathrm{MHz}, \mathrm{DMSO}-\mathrm{d}_{6}\right) \delta(\mathrm{ppm}) 12.25(\mathrm{~s}, 1 \mathrm{H}), 9.1(\mathrm{~s}, 1 \mathrm{H}), 8.75(\mathrm{~d}, 1 \mathrm{H}), 8.2(\mathrm{~d}, 1 \mathrm{H}), 8.0(\mathrm{~s}, 1 \mathrm{H})$, $7.5(\mathrm{t}, 1 \mathrm{H}), 3.7(\mathrm{~m}, 8 \mathrm{H}) ; \mathrm{m} / \mathrm{z}: 319(\mathrm{M}+1)$

\section{N-(4-(thiomorpholine-4-carbonyl) thiazol-2-yl) nicotinamide (5i)}

${ }^{1} \mathrm{H}-\mathrm{NMR}(400 \mathrm{MHz}$, DMSO-d 6 ) $\delta$ (ppm) 12.40 (s, 1H), $9.14(\mathrm{~s}, 1 \mathrm{H}), 8.75(\mathrm{~d}, 1 \mathrm{H}), 8.31-8.27(\mathrm{~d}, 2 \mathrm{H}), 7.60-$ $7.58(\mathrm{~s}, 1 \mathrm{H}), 3.34-3.32(\mathrm{t}, 4 \mathrm{H}), 3.14-3.12(\mathrm{t}, 4 \mathrm{H}) ;{ }^{13} \mathrm{C}-\mathrm{NMR}\left(128 \mathrm{MHz}, \mathrm{DMSO}-\mathrm{d}_{6}\right) \delta(\mathrm{ppm}) 165.2,161.8$, $160.7,152.2,149.6,149.1,136.5,133.6,131.5,124.5,117.7,47,28.2 ; \mathrm{m} / \mathrm{z}: 335(\mathrm{M}+1)$

\section{Chemistry}

\section{RESULTS AND DISCUSSION}

This research work successfully synthesized the series of nine diamide and one amide compound from the thiamine and thiazole amine ester for the antibacterial study as per Scheme-1. For the synthesis, this work used EDCI reagent which is easy to work-up, good yield with good purity. The reaction yield, molecular weight, Melting Point and TLC Rf Value are presented in Table-1.

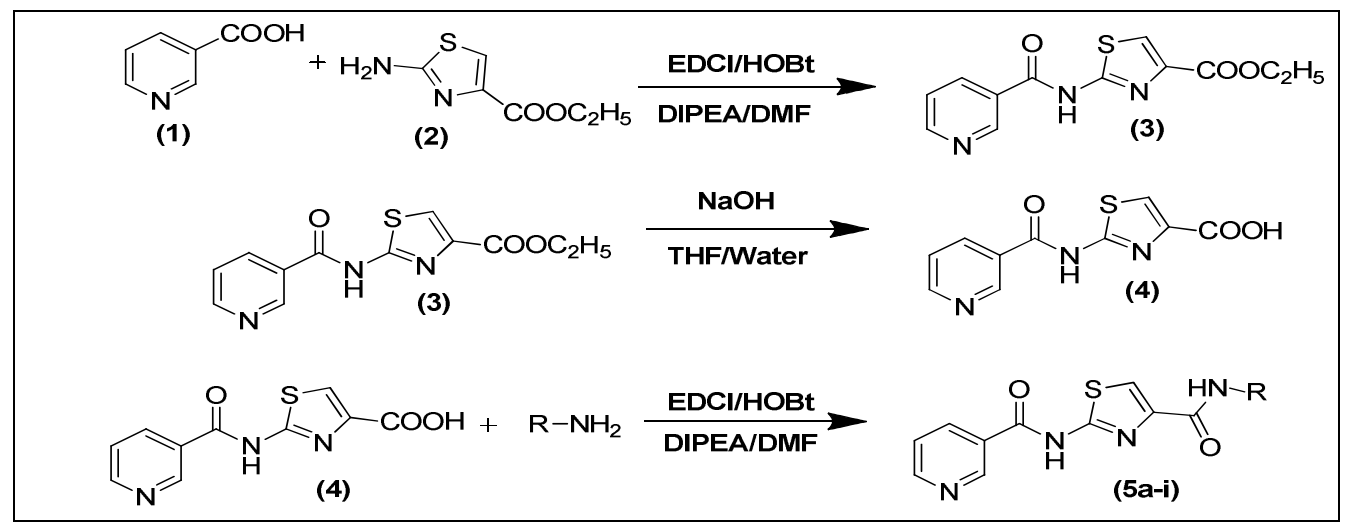

Scheme-1: Preparation of Nicotinamide Thiazole Compounds 5a-5i

From the table result, this work identified that polarity of the derivatives is lower than the starting material and their melting points are somehow higher due to the diamide group and molecular weight of the compounds. Based on the Rf value difference and physical properties, all synthesized derivatives were carried for ${ }^{1} \mathrm{H}-\mathrm{NMR}$ and Mass spectral characterization. The ${ }^{1} \mathrm{H}-\mathrm{NMR}$ results exposed that the pyridine nitrogen neighboring singlet proton identified between $12.4 \mathrm{ppm}$ and $12.2 \mathrm{ppm}$. Amide protons were identified between $8.7 \mathrm{ppm}$ and $8.3 \mathrm{ppm}$ in all compounds. ${ }^{16}$ Similarly triplet and doublet protons of compound 3 vanished in compound $\mathbf{4}$. This absent confirmed the ester hydrolyzed product (4). Compound 


\section{RASĀYAN J. Chem.}

Vol. 12 | No. 4 |2005 - 2010| October - December | 2019

4 carboxyl proton at $11.1 \mathrm{ppm}$ was absent in the series of compounds 5a to 5i. But the proton number increased and one more amide peak maybe exists at the aliphatic regions based on the substituents used for the preparation. After the ${ }^{1} \mathrm{H}-\mathrm{NMR}$ characterizations, the molecules were characterized by mass spectroscopy to confirm the molecular ion peak and confirmed the derivatives with the resultant peaks. The difference observed between the compound $\mathbf{3}$ and $\mathbf{4}$ is 30 which confirm the ester hydrolyzed product. Likewise, molecular mass differences between $\mathbf{4}$ and $\mathbf{5 a - 5 i}$ confirmed the substituted molecular mass and the derived compounds were characterized successfully using ${ }^{1} \mathrm{H}-\mathrm{NMR}$ and Mass spectral technique. The characterized compounds were carried for the antimicrobial study. More active compound 5i ${ }^{1} \mathrm{H}-\mathrm{NMR}$ and ${ }^{13} \mathrm{C}$ - NMR is displayed in Fig.-1 and Fig.-2.

Table-1: Compounds Yield, Melting Point and TLC $\mathrm{R}_{\mathrm{f}}$ Value

\begin{tabular}{c|l|l|c|c|c|c}
\hline Comp.ID & \multicolumn{1}{|c|}{ R group } & \multicolumn{1}{|c|}{$\begin{array}{c}\text { Molecular } \\
\text { formula }\end{array}$} & $\begin{array}{c}\text { Molecular } \\
\text { weight }\end{array}$ & $\begin{array}{c}\text { Yield in } \\
\%\end{array}$ & $\begin{array}{c}\text { Melting point } \\
\left({ }^{\circ} \mathrm{C}\right)\end{array}$ & $\begin{array}{c}\mathrm{R}_{\mathrm{f}} \\
\text { Value }\end{array}$ \\
\hline 3 & --- & $\mathrm{C}_{12} \mathrm{H}_{11} \mathrm{~N}_{3} \mathrm{O}_{3} \mathrm{~S}$ & 277 & 85 & $252-255$ & 0.60 \\
\hline 4 & --- & $\mathrm{C}_{10} \mathrm{H}_{7} \mathrm{~N}_{3} \mathrm{O}_{3} \mathrm{~S}$ & 249 & 78 & $245-248$ & 0.40 \\
\hline $5 \mathrm{a}$ & $\mathrm{C}_{6} \mathrm{H}_{5}$ & $\mathrm{C}_{16} \mathrm{H}_{12} \mathrm{~N}_{4} \mathrm{O}_{2} \mathrm{~S}$ & 324 & 88 & $275-278$ & 0.75 \\
\hline $5 \mathrm{~b}$ & Cyclopropyl & $\mathrm{C}_{13} \mathrm{H}_{12} \mathrm{~N}_{4} \mathrm{O}_{2} \mathrm{~S}$ & 288 & 84 & $255-258$ & 0.80 \\
\hline $5 \mathrm{c}$ & Cyclobutyl & $\mathrm{C}_{14} \mathrm{H}_{14} \mathrm{~N}_{4} \mathrm{O}_{2} \mathrm{~S}$ & 302 & 82 & $263-268$ & 0.85 \\
\hline $5 \mathrm{~d}$ & Cyclopentyl & $\mathrm{C}_{15} \mathrm{H}_{16} \mathrm{~N}_{4} \mathrm{O}_{2} \mathrm{~S}$ & 316 & 80 & $273-278$ & 0.90 \\
\hline $5 \mathrm{e}$ & Cyclohexyl & $\mathrm{C}_{16} \mathrm{H}_{18} \mathrm{~N}_{4} \mathrm{O}_{2} \mathrm{~S}$ & 330 & 89 & $295-300$ & 0.95 \\
\hline $5 \mathrm{f}$ & Adamantyl & $\mathrm{C}_{20} \mathrm{H}_{22} \mathrm{~N}_{4} \mathrm{O}_{2} \mathrm{~S}$ & 382 & 81 & $350-355$ & 0.95 \\
\hline $5 \mathrm{~g}$ & $\begin{array}{l}\text { N-methyl } \\
\text { piperazinyl }\end{array}$ & $\mathrm{C}_{15} \mathrm{H}_{17} \mathrm{~N}_{5} \mathrm{O}_{2} \mathrm{~S}$ & 331 & 86 & $268-273$ & 0.65 \\
\hline $5 \mathrm{~h}$ & Morphinyl & $\mathrm{C}_{14} \mathrm{H}_{14} \mathrm{~N}_{4} \mathrm{O}_{3} \mathrm{~S}$ & 318 & 89 & $272-275$ & 0.70 \\
\hline $5 \mathrm{i}$ & Thiomorphinyl & $\mathrm{C}_{14} \mathrm{H}_{14} \mathrm{~N}_{4} \mathrm{O}_{2} \mathrm{~S}_{2}$ & 334 & 88 & $288-293$ & 0.75 \\
\hline
\end{tabular}

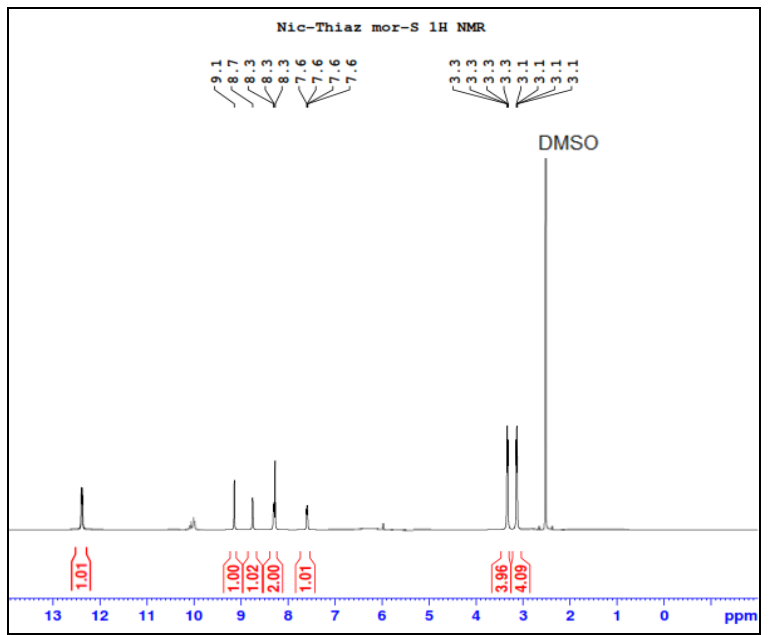

Fig.-1: ${ }^{1} \mathrm{H}-\mathrm{NMR}$ of $5 \mathrm{i}$

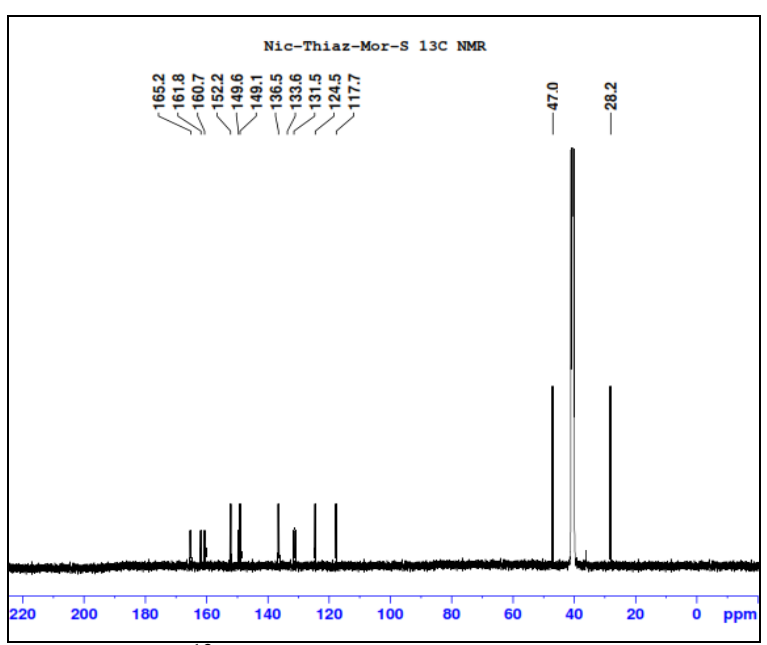

Fig.-2: ${ }^{13} \mathrm{C}-\mathrm{NMR}$ of $5 \mathrm{i}$

\section{Antimicrobial Activity}

The derived compounds were carried for the inhibition study using the paper disc diffusion method to evaluate the in-vitro anti-microbial activity in terms of inhibition zone in millimeter. The anti-microbial activity of the synthesized compounds was screened against the following bacteria and fungi using the reported methods. ${ }^{17}$ Ciprofloxacin and Ketoconazole were used as standard drugs for the inhibition assay. Ciprofloxacin $(5 \mathrm{mcg} / \mathrm{disc})$ and Ketoconazole $(50 \mathrm{mcg} / \mathrm{disc})$ were used as standard for anti-bacterial and anti-fungal activities and compared with the $200 \mathrm{ppm}$. The results have shown in Table- 2 .

From the antimicrobial activity results, this work revealed that the thio morphinyl attached diamide exhibited good inhibition ability against pathogens. Also, 5i showed very good result against the fungus 
RASĀYAN J. Chem.

Vol. 12 | No. 4 |2005 - 2010| October - December | 2019

when compared to the fungus standard. Most of the compounds showed good results when compared to starting materials. The antimicrobial plates of the $\mathbf{5 i}$ have shown in Fig.-3.

Table- 2: Antimicrobial Zone of Inhibition Results for the Derivatives

\begin{tabular}{l|l|l|l|l|l}
\hline Compounds & S.aureus & S.epidermidis & E. coli & K.pneumonia & C.albicans \\
\hline 3 & 24 & 26 & 24 & 15 & 18 \\
\hline 4 & 25 & 27 & 26 & 16 & 21 \\
\hline $5 \mathrm{a}$ & 25 & 28 & 18 & 20 & 24 \\
\hline $5 \mathrm{~b}$ & 24 & 27 & 20 & 18 & 23 \\
\hline $5 \mathrm{c}$ & 25 & 26 & 24 & 16 & 24 \\
\hline $5 \mathrm{~d}$ & 26 & 25 & 25 & 18 & 25 \\
\hline $5 \mathrm{e}$ & 27 & 28 & 28 & 20 & 27 \\
\hline $5 \mathrm{f}$ & 28 & 29 & 28 & 18 & 28 \\
\hline $5 \mathrm{~g}$ & 28 & 29 & 26 & 24 & 27 \\
\hline $5 \mathrm{~h}$ & 32 & 30 & 30 & 25 & 29 \\
\hline $5 \mathrm{i}$ & 34 & 32 & 32 & 27 & 31 \\
\hline Ciprofloxacin & 35 & 30 & 32 & 28 & --- \\
\hline Ketaconazole & --- & --- & --- & --- & 30 \\
\hline
\end{tabular}

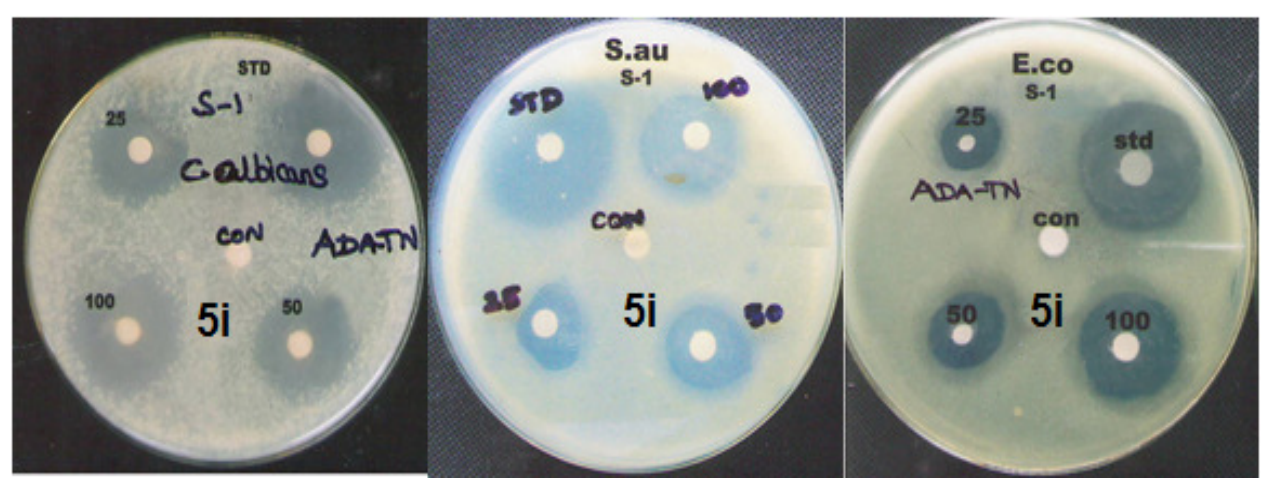

Fig.-3: Antimicrobial Test Plates of 5i

\section{CONCLUSION}

In this research, synthesized and characterized the Nicotinamide-thiazole derivatives were successfully investigated for their antibacterial and antifungal ability. All the compounds were bio-active and 5i was found to possess significant activity. Finally, this research concluded that the diamide containing heterocyclic molecules have shown good biological activity results. In addition to the biological work, this work will be extended for their anti-cancer activity on cell lines in future.

\section{ACKNOWLEDGMENT}

One of author, H.V wants to Dean, MIT campus, Prof. Shanthi, Chemistry HOD, CEG, Dr.K.M.Veerabadran, Chemistry in Charge, MIT campus for constant encouragement and helping Lab \& Analytical facilities.

\section{REFERENCES}

1. R. A. A. Mothana and U. Lindequist, Journal of Ethnopharmacology, 96 (2), 177(2005), DOI: 10.1016/j.jep.2004.09.006.

2. S. Manandhar, S. Luitel, and R. K. Dahal, J. Trop. Med, 2019, 1(2019), DOI: 10.1155/2019/1895340

3. A.K.Ghose, V.N.Viswanadhan, J.J.Wendoloski, J.Comb.Chem., 1, 55(1999)

4. Pierre Kyme, Nils H.Thoennissen, Ching Wen Tseng, Gabriel B.Thoennissen, Andrea J.Wolf, Kenichi shimada, Utz O.Krug, Kunik Lee, Carsten Muller-Tidow, Wolfgang E.Berdel, W.David, Hardy, and Adrian F.Gombart, Journal of Clinical Investigation, 2012, DOI: 10.1172/JCI62070

5. G.L. Patrick, An Introduction to Medical Chemistry-Second Edition (2001), Oxford University Press, Oxford. 


\section{RASĀYAN J. Chem.}

Vol. 12 | No. 4 |2005 - 2010| October - December | 2019

6. Christian Montalbetti and Virginie Falque, Tetrahedron,61, 10827(2005)

7. J. Quiroga, P. Hernandez, B. Insuasty, R. Abonia, J. Cobo, A. Sanchez, M. Nogueras and J.N. Low, J. Chem. Soc., Perkin Trans., 1(4),555 (2002), DOI:10.1039/b109676a.

8. I. Hutchinson, S. A. Jennings, B. R. Vishnu vajjala, A. D. Westwell and M. F. G. Stevens, J. Med.Chem., 45, 744(2002), DOI: 10.1021/jm011025r.

9. M. T. Chhabria, S. Patel, P. Modi and P. S. Brahmkshatriya, Curr. Top. Med. Chem., 16, 2841 (2016), DOI:10.2174/1568026616666160506130731.

10. K. Sampath, K. Karthik, R. Sivahari, P. Arunkumar, Rasayan J. Chem., 10, 1184(2017), DOI:10.31788/RJC.2018.1143080.

11. P. Karegoudar, M. S. Karthikeyan, D. J. Prasad, M. Mahalinga, B. S. Holla and N. S. Kumari, Eur. J. Med. Chem, 43, 261(2008), DOI: 10.1016/j.ejmech.2007.03.014.

12. P. Vicini, A. Geronkiaki, M. Incerti, F. Zani, J. Dearden and M. Hewitt, Bioorg. Med. Chem., 16, 3714 (2008), DOI: 10.1016/j.bmc.2008.02.001.

13. R. P. Karuvalam, K. R. Haridas, S. K. Nayak, T.N. Guru Row, P.Rajesh, R.Rishikesan, N. Suchetha Kumari, Eur. J. Med. Chem., 49,172 (2012), DOI: 10.1016/j.ejm ech. 2012. 01.008.

14. A Andreani, M. Rambaldi, A. Leoni, A. Locatelli, R. Bossa, M. Chiericozzi, I. Galatulas and G.Salvatore, Eur. J. Med. Chem., 31, 383 (1996), DOI: 10.1016/S0223-5234(99) 80015-4.

15. B Jiang and X.- H. Gu, Bioorg. Med. Chem., 8, 363(2000), DOI: 10.1016/S0968-0896(99)00290-4.

16. M. Peng, L. Shi, S. Ke, Chem.Cen. J., 11(109), 1(2017), DOI: 10.1186/s13065-017-0338-5.

17. K. Hassan and M.E. Bagoury, Rasayan J. Chem., 11(1), 238(2018), DOI: 10.7324/RJC.2018.1112019

[RJC-5321/2019] 